7 - ORIGINAL ARTICLE

ISCHEMIA-REPERFUSION

\title{
The antioxidant effect of dexmedetomidine on testicular ischemia-reperfusion injury ${ }^{1}$
}

\author{
Devrim Tuglü, Ercan Yuvanc ${ }^{\mathrm{II}}$, Erdal Yılmaz ${ }^{\mathrm{III}}$, Isin Yazici Gencay ${ }^{\mathrm{IV}}$, Pinar Atasoy ${ }^{\mathrm{V}}$, Ucler Kisa ${ }^{\mathrm{VI}}$, Ertan Batislam ${ }^{\mathrm{VII}}$ \\ DOI: http://dx.doi.org/10.1590/S0102-865020150060000007
}

IAssistant Professor, Department of Urology, Medical Faculty, University of Kirikkale, Kirikkale, Turkey. Design of the study, analyzed of data,
technical procedures, manuscript writing.
IIAssistant Professor, Department of Urology, Medical Faculty, University of Kirikkale, Kirikkale, Turkey. Technical procedures, acquisition of data,
manuscript writing.
IIIFull Professor, Department of Urology, Medical Faculty, University of Kirikkale, Kirikkale, Turkey. Intellectual and scientific content of the study,
statistical analysis, critical revision, final approval of the manuscript.
IVAssistant Professor, Department of Anesthesiology and Reanimation, Medical Faculty, University of Kirikkale, Kirikkale, Turkey. Conception and
design of the study, interpretation of data.
Vull Professor, Department of Pathology, Medical Faculty, University of Kirikkale, Kirikkale, Turkey. Macroscopic and histopathological examinations.
VIFull Professor, Department of Biochemistry, Medical Faculty, University of Kirikkale, Kirikkale, Turkey. Performed biochemical results.
VIIFull Professor, Department of Urology, Medical Faculty, University of Kirikkale, Kirikkale, Turkey. Critical revision, final approval of the manuscript.

\section{ABSTRACT}

PURPOSE: To investigate the protective effect of dexmedetomidine (Dex) on testicular damage induced by ischemia-reperfusion injury in rats.

METHODS: Sham group underwent left scrotal exploration only (group 1). The ischemia-reperfusion only group underwent left testicular torsion and detorsion (group 2). The ischemia-reperfusion plus Dex group underwent left testicular torsion, received $50 \mu \mathrm{g} / \mathrm{kg}$ Dex (group 3) and $100 \mu \mathrm{g} / \mathrm{kg}$ Dex (group 4) intraperitoneally at minute 180 of ischemia and then underwent detorsion. We determined histopathological findings and performed specific biochemical analyses.

RESULTS: Increasing doses of Dex significantly increased TAS, and significantly decreased OSI. Analyzing the antioxidant effects of increasing doses of Dex in torsion and contrlateral testicles: Dex $100 \mu \mathrm{g} / \mathrm{kg}$ statistically significant increased the tissue total antioxidant status (TAS) and oxidative stress index (OSI) when compared with Dex $50 \mu \mathrm{g} / \mathrm{kg}$ but not found significantly change on the tissue total oxidant status (TOS). However, Dex did not significantly improve these histological alterations.

CONCLUSION: The antioxidant effects of dexmedetomidine on testicular ischemia-reperfusion injury in ipsilateral and contrlateral testis, but in the histopathological level, there was no difference statistically according to Johnsen's scoring system between groups at both sides.

Key words: Dexmedetomidine. Spermatic Cord Torsion. Antioxidants. Reperfusion Injury. Testis. Rats. 


\section{Introduction}

Testicular torsion is a urologic emergency that observes commonly in the neonatal and adolescent period and is a pathological condition which reveals with testicular ischemia and surgery is generally required to restore blood flow ${ }^{1,2}$. Testicular recovery requires early reestablish of blood flow. Although reperfusion is absolutely necessary for the survival of ischemic tissue, reperfusion damage eventuates by generation of reactive oxygen species (ROS) on resumption of blood flow ${ }^{3}$. The basic pathological mechanisms underlying ischemia-reperfusion injury (IRI) of the tissue has not yet been exactly understood. On the other hand, this oxidative stress is associated with an imbalance between cellular antioxidative systems and $\operatorname{ROS}^{3}$. As a consequence of the reperfusion of the ischemic tissue, toxic-free oxygen radicals, such as nitric oxide $\left(\mathrm{NO}^{-}\right)$, superoxide anions $\left(\mathrm{O}_{2}^{-}\right)$, hydrogen peroxide $\left(\mathrm{H}_{2} \mathrm{O}_{2}\right)$, and hydroxyl radicals $\left(\mathrm{OH}^{-}\right)$are released ${ }^{1,4,5}$. Moreover, in cases where repeated succession of IRI in testicular cells cause many biochemical and morphological changes which may lead to lipid peroxidation, protein denaturation, DNA damage and apoptosis ${ }^{6}$.

Dexmedetomidine (Dex), a selective and potent $\alpha_{2}$ adrenoceptor agonist, was approved by the U.S Food and Drug Administration in 1999 for sedation of patients hospitaliaed in intensive care settings. Since then, a growing number of research articles have emerged reporting other possible indications, such as regional ${ }^{7}$ and general anesthesia ${ }^{8}$. In addition to sedative and analgesic effects, organ-protective effects of Dex have been shown in several inflammatory models, including IRI ${ }^{9}$.

Due of the antioxidative properties of Dex, it seems possible that using Dex before ischemia/reperfusion may protect the testis tissue against oxidative $\mathrm{I} / \mathrm{R}$ injury. To the best of our knowledge, there has been such a report in the literature. In the present study, we therefore tried to determine whether different doses of Dex could prevent in vivo rat model of torsione/detorsione testis and contrlateral testis injury-induced by I/R by measuring oxidant parameters, such as total oxidative status (TOS), oxidative stress index (OSI), and antioxidative parameters such as total antioxidant capacity (TAS) in the torsione testis and contrlateral testis tissue. We also examined histopathological alterations in the tissue. Another object of the study was to evaluate the effect of different doses of Dex on contralateral testicular histology following unilateral testicular torsion. On the other hand, of course, to find a drug that can be used clinically have a great importance to reduce testicular damage of the testicles before reperfusion period.

\section{Methods}

Local ethics committee approval was obtained. Sixmonth-old Wistar albino male rats weighing 250-300 g were used in the study. During investigation, rats were housed at an ambient temperature of $22{ }^{\circ} \mathrm{C}$, with a light cycle of 12-hours of light and 12-hours of dark, and 40\%-70\% humidity. Rats were fed pellet rat feed and tap water.

Before interventional procedures, ketamine $\mathrm{HCl}(90 \mathrm{mg}$ / $\mathrm{kg})$ and xylazine $(10 \mathrm{mg} / \mathrm{kg})$ were administered intramuscularly for general anesthesia.

Rats were randomized into 4 groups: group $1=$ Sham $(\mathrm{n}=8)$, group $2=\mathrm{I} / \mathrm{R}(\mathrm{n}=8)$, and group $3=\mathrm{I} / \mathrm{R}+\operatorname{Dex} 50 \mu \mathrm{g} / \mathrm{kg}$ $(\mathrm{n}=8)$, group $4=\mathrm{I} / \mathrm{R}+\operatorname{Dex} 100 \mu \mathrm{g} / \mathrm{kg}(\mathrm{n}=8)$.

For group 1 (Sham), the left testis was accessed by scrotal incision and dissected. The scrotum was then closed with $5 / 0$ silk suture without carrying out any procedure.

For group 2 (I/R), the left testis was accessed by scrotal incision and dissected. The testis was torsed 720 counter clockwise and fixed to the wall of the scrotum with $5 / 0$ silk suture. The scrotum was closed with $5 / 0$ silk with the testis torsed. The testis was detorsioned after 4 hours of torsion. The scrotum was closed again with $5 / 0$ silk.

For group $3(\mathrm{I} / \mathrm{R}+\operatorname{Dex} 50 \mu \mathrm{g} / \mathrm{kg})$, in addition to the procedures carried out in group 2, $50 \mu \mathrm{g} / \mathrm{kg}$ of Dex was administered intraperitoneally (i.p.) to each rat 60 minutes before detorsion.

For group $4((\mathrm{I} / \mathrm{R}+\operatorname{Dex} 100 \mu \mathrm{g} / \mathrm{kg})$, in addition to the procedures carried out in group 2, $100 \mu \mathrm{g} / \mathrm{kg}$ of Dex was administered intraperitoneally (i.p.) to each rat 60 minutes before detorsion.

Six hours after initiation of the experimental procedure, the left and right testes of rats in all 4 groups were removed for histological and biochemical measurements examination.

\section{Histological evaluation}

Testis tissues were fixed with 10\% neutral formalin and parafin blocks were obtained by a routine procedure. Sections obtained from these blocks were subjected to hematoxylin and eosin staining. A light microscope with camera attachment (Olympus DP 71; Olympus, Tokyo, Japan) was used for evaluation. The tissues were examined under a light microscope and the microscopic scoring was graded on a scale of mild $(+)$, moderate $(++)$ and severe $(+++)$. Spermatogenesis was assessed histopathologically using Johnsen's mean testicular biopsy score 
(MTBS) criteria $^{10}$. Tubuli in 10 consequtive $\mathrm{x} 400$ field areas were scored and mean values were determined. The Johnsen score is based on the premise that with testicular damage there is successive disappearance of the most mature cell type, with progressive degeneration of germinal epithelium, with the disappearance of spermatozoa and spermatids, then spermatocytes and finally Sertoli cells, in that order. A score of 1 to 10 was given to each tubule according to the maturity of the germ cells: A score of 1 indicated no seminiferous epithelial cells and tubular sclerosis. A score of 2 indicated no germ cells, only Sertoli cells. A score of 3 indicated spermatogonia only. A score of 4 indicated no spermatids, few spermatocytes, and arrest of spermatogenesis at the primary spermatocyte stage. A score of 5 indicated no spermatids and many spermatocytes. A score of 6 indicated no late spermatids, few early spermatids, arrest of spermatogenesis at the spermatid stage, and disturbance of spermatid differentiation. A score of 7 indicated no late spermatids and many early spermatids. A score of 8 indicated few late spermatids. A score of 9 indicated many late spermatids and disorganized tubular epithelium. A score of 10 indicated full spermatogenesis. All histologic evaluations were performed by an experienced pathologist.

\section{Biochemical evaluation}

Blood samples were obtained after suitable centrifugation and samples were stored frozen at $-80{ }^{\circ} \mathrm{C}$ until day of analysis.

Measurement of Total Antioxidant Status (TAS) level was determined using method developed by Erel ${ }^{11}$. Tissue TAS levels were calculated in mmol Trolox equivalent/L. Measurement of Total Oxidant Status (TOS) levels were determined using method as previously described by Erel. Tissue TOS levels were calculated in $\mu \mathrm{mol} \mathrm{H} 2 \mathrm{O} 2$ equivalent/L. TOS levels of all tissues were determined using a novel automated measurement method, developed by $\mathrm{Erel}^{12}$. In this method, oxidants present in the sample oxidize the ferrous ion-o-dianisidine complex to ferric ion. The oxidation reaction is enhanced by glycerol molecules, which are abundantly present in the reaction medium. The ferric ion makes a colored complex with xylenol orange in an acidic medium. The color intensity, which can be measured spectrophotometrically, is related to the total amount of oxidant molecules present in the sample. The assay is calibrated with hydrogen peroxide, and the results are expressed in terms of micromolar hydrogen peroxide equivalent per gram protein (micromoles $\mathrm{H}_{2} \mathrm{O}_{2}$ equivalents per gram protein).

Calculation of Oxidative stress index (OSI): The TOS:TAS ratio was used as the OSI. To perform the calculation, the unit of TAS, mmol Trolox equivalent/L, was converted to $\mu$ mol Trolox equivalent/L, and OSI was calculated as follows: OSI $=[(\mathrm{TOS}, \mu \mathrm{mol} \mathrm{H} 2 \mathrm{O} 2$ equivalent/L)/(TAS, $\mu \mathrm{mol}$ Trolox equivalent/L) $\times 100]^{12}$.

\section{Statistical analysis}

All statistical analysis was performed using SPSS version 15.0 (SPSS; Chicago, IL, USA). The normally distributed data are presented as mean \pm standard deviation (SD) and non-normally distributed data are expressed as median (25\% - 75\%). Student $\mathrm{t}$ and One way ANOVA test with Bonferroni adjustment were used for comparing normally distributed data. Mann Whitney $U$ and Kruskal Wallis test with Bonferroni adjustment were used for comparing non-normally distributed data. Subsequently, the relation between these parameters was evaluated using linear regression analysis (Backward). A $p<0.05$ was accepted as statistically significant.

\section{Results}

The ipsilateral and contralateral testis median TAS, TOS, OSI levels are presented on Tables I and II. Median ipsilateral testis TAS levels were respectively, $1.81(0.83-4.75)$ in group $1,1.01(0.27-2.19)$ in group 2, $9.22(8.48-10.07)$ in group 3 and 9.77 (8.21-10.31) in group 4. There were significant differences between groups 1 and $2(p<0.001), 1$ and $3(p<0.001), 1$ and 4 $(\mathrm{p}<0.001), 2$ and $3(\mathrm{p}<0.001), 2$ and $4(\mathrm{p}<0.001)$, and 3 and 4 $(p<0.001)$ in terms of tissue TAS levels. Median TOS levels were respectively, $1.65(0.49-2.78)$ in group $1,1.14(0.72-3.25)$ in group $2,1.51(1.27-1.63)$ in group 3 and $1.47(0.94-2.81)$ in group 4. There were non significant differences between all groups. Median OSI levels were respectively, $1.35(0.40-1.77)$ in group $1,0.97$ $(0.68-3.30)$ in group $2,0.17(0.12-0.18)$ in group 3 and 0.15 $(0.08-0.39)$ in group 4 . There were significant between groups 1 and $2(\mathrm{p}<0.001), 1$ and $3(\mathrm{p}<0.001), 1$ and $4(\mathrm{p}<0.001), 2$ and 3 $(p<0.001), 2$ and $4(p<0.001)$, and 3 and $4(p<0.001)$ in terms of tissue OSI levels (Table 1). 
TABLE 1 - Oxidative and antioxidative parameters in sham, control, and Dex. $50 \mu \mathrm{g} / \mathrm{kg}$, Dex. $100 \mu \mathrm{g} / \mathrm{kg}$ treatment groups.

\begin{tabular}{|c|c|c|c|c|c|}
\hline & $\begin{array}{c}\text { Group1 } \\
n=8 \\
\text { (Sham) }\end{array}$ & $\begin{array}{c}\text { Group2 } \\
\mathbf{n}=\mathbf{8} \\
(\mathrm{I} / \mathbf{R})\end{array}$ & $\begin{array}{c}\text { Group3 } \\
n=8 \\
(\mathrm{I} / \mathrm{R}+\text { Dex. } 50 \mu \mathrm{g} / \mathrm{kg})\end{array}$ & $\begin{array}{c}\text { Group4 } \\
\mathrm{n}=\mathbf{8} \\
(\mathrm{I} / \mathrm{R}+\text { Dex. } 100 \mu \mathrm{g} / \mathrm{kg})\end{array}$ & $\begin{array}{c}\text { p } \\
\text { Kruskal } \\
\text { Wallis }\end{array}$ \\
\hline $\begin{array}{l}\text { TAC } \\
\text { (nmol Trolox Equiv. } \\
\text { per mg protein) }\end{array}$ & $1.81(0.83-4.75)$ & $1.01(0.27-2.19)$ & $9.22(8.48-10.07)$ & $9.77(8.21-10.31)$ & $\mathrm{p}<0.001$ \\
\hline $\begin{array}{l}\text { TOS } \\
\text { (nmol H2O2 Equiv. } \\
\text { per mg protein) }\end{array}$ & $1.65(0.49-2.78)$ & $1.14(0.72-3.25)$ & $1.51(1.27-1.63)$ & $1.47(0.94-2.81)$ & NS \\
\hline $\begin{array}{l}\text { OSI } \\
\text { (arbitrary unit) }\end{array}$ & $1.35(0.40-1.77)$ & $0.97(0.68-3.30)$ & $0.17(0.12-0.18)$ & $0.15(0.08-0.39)$ & $\mathrm{p}<0.001$ \\
\hline
\end{tabular}

Kruskal Wallis Test, Median (25-75\%), p<0.05 NS: Statistically non significant.

Values are mean $\pm \mathrm{SD}$. OSI, oxidative stress index; TAC, total antioxidant capacity; TOS, total oxidative status.

Median contrlateral testis TAS levels were respectively, $1.81(0.83-4.75)$ in group $1,1.24(0.40-2.16)$ in group 2 right testis, 3.07 (1.34-3.68) in group 3 right testis and 7.88 (7.18$8.65)$ in group 4 right testis. There were significant differences between groups 1 and 2 right testis $(\mathrm{p}<0.001), 1$ and 3 right testis $(\mathrm{p}<0.001), 1$ and 4 right testis $(\mathrm{p}<0.001), 2$ and 3 right testis $(\mathrm{p}<0.001), 2$ and 4 right testis $(\mathrm{p}<0.001)$, and 3 and 4 right testis $(p<0.001)$ in terms of tissue TAS levels. Median contrlateral testis TOS levels were respectively, $1.65(0.49-2.78)$ in group 1 , 1.72 (1.62-2.88) in group 2 right testis, 2.38 (1.57-2.89) in group
3 right testis and $1.53(1.07-1.83)$ in group 4 right testis. There were non significant differences between all groups. Median contrlateral testis OSI levels were respectively, 1.35 (0.40-1.77) in group $1,1.09(0.78-7.27)$ in group 2 right testis, $0.75(0.60$ $1.45)$ in group 3 right testis and $0.18(0.12-0.24)$ in group 4 right testis. There were significant differences between groups 1 and 2 right testis $(p<0.001), 1$ and 3 right testis $(p<0.001), 1$ and 4 right testis $(p<0.001), 2$ and 3 right testis $(p<0.001), 2$ and 4 right testis $(p<0.001)$, and 3 and 4 right testis $(p<0.001)$ in terms of tissue OSI levels (Table 2).

TABLE 2 - Oxidative and antioxidative parameters in sham, control, and Dex. $50 \mu \mathrm{g} / \mathrm{kg}$, Dex. $100 \mu \mathrm{g} / \mathrm{kg}$ treatment groups in contralateral testes groups.

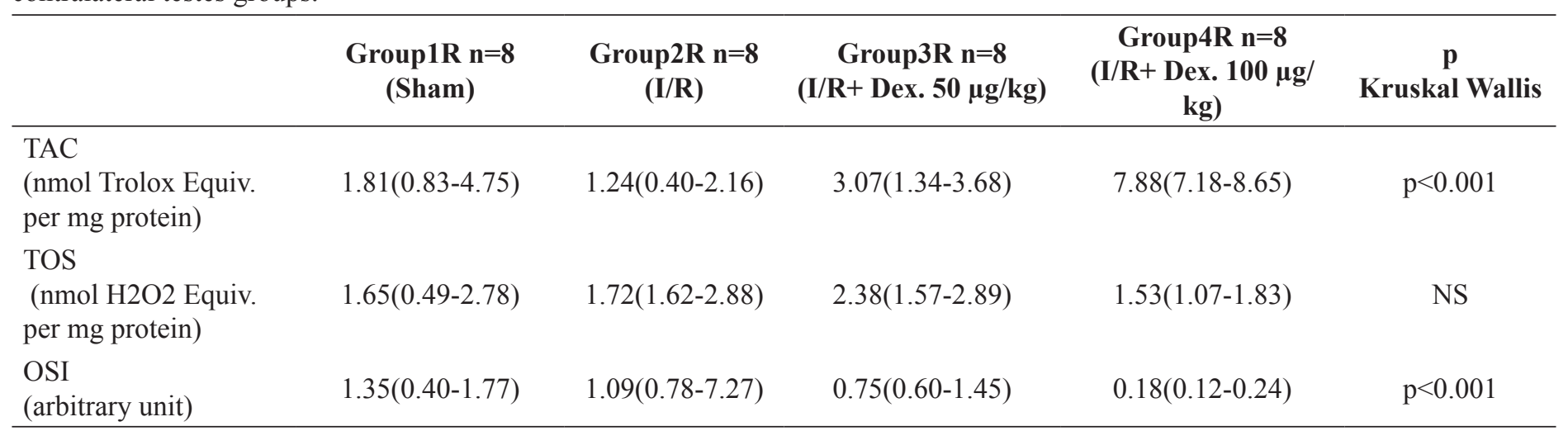

Kruskal Wallis Test, Median (25-75\%), p $<0.05$ NS: Statistically non significant.

Values are mean $\pm \mathrm{SD}$. OSI, oxidative stress index; TAC, total antioxidant capacity; TOS, total oxidative status.

Normal findings were obtained on histological examination of rats in group 1 (Figure 1). In untreated T/D group 2, note interstitial edema, hemorrhage and less distinct seminiferous tubule borders (Figure 2). In Dexemedetomidin $50 \mu \mathrm{g} / \mathrm{kg}$ treated group 3, note reduced edema, hemorrhage and well organized germ cells (Figure 3). In Dexemedetomidin 100 $\mu \mathrm{g} / \mathrm{kg}$ treated group 4, note reduced edema, hemorrhage and well organized germ cells (Figure 4). There was no difference statistically according to Johnsen's scoring system between groups at both sides (Table 3 ). 


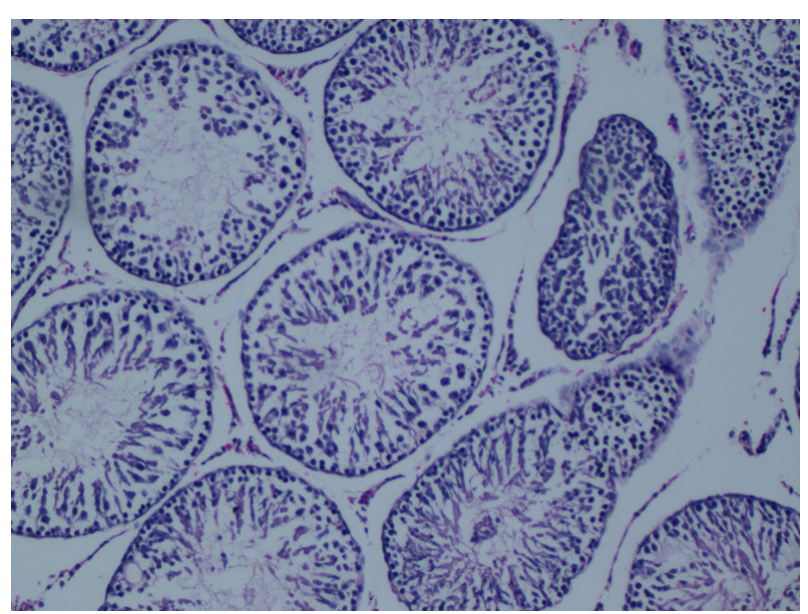

FÍGURE 1 - Photomicrographs shows left testes. Sham operated group 1. Note normal seminiferous tubules (H\&E, x100).

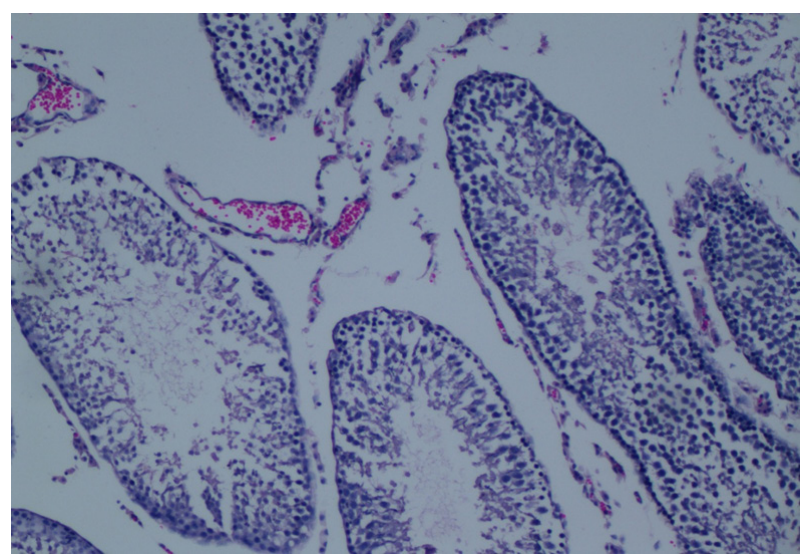

FIGURE 3 - Dexemedetomidin $50 \mu \mathrm{g} / \mathrm{kg}$ treated group 3. Note reduced edema, hemorrhage and well organized germ cells (H\&E, x100).

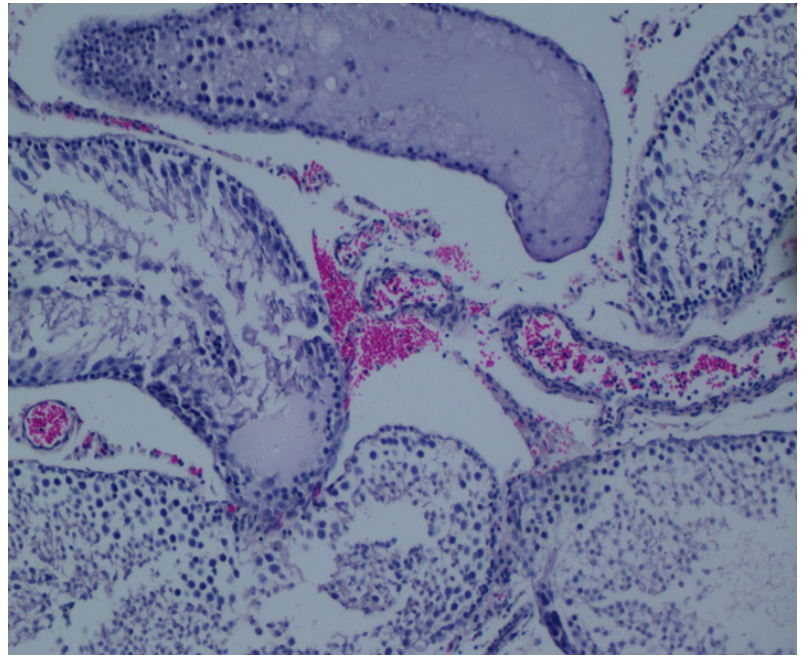

FIGURE 2 - Untreated T/D group 2. Note interstitial edema, hemorrhage and less distinct seminiferous tubule borders (H\&E, x100).

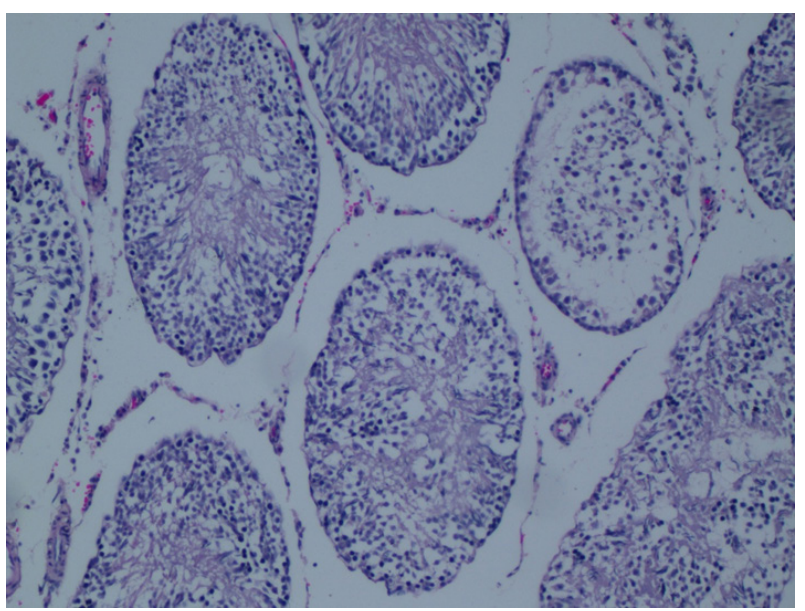

FIGURE 4 - Dexemedetomidin $100 \mu \mathrm{g} / \mathrm{kg}$ treated group 4 . Note reduced edema, hemorrhage and well organized germ cells (H\&E, x100).

TABLE 3 - Degrees of some histopathological lesions of testicular sections of rats in all groups [mild (+), moderate (++), severe $(+++)]$.

\begin{tabular}{|c|c|c|c|c|c|c|c|}
\hline Parameters & $\begin{array}{c}\text { Group 1 } \\
(\mathrm{n}=8) \\
\text { (Sham) }\end{array}$ & $\begin{array}{c}\text { Group 2 } \\
(\mathrm{n}=\mathbf{8}) \\
(\mathrm{I} / \mathrm{R})\end{array}$ & $\begin{array}{c}\text { Group } 3(\mathrm{n}=8) \\
(\mathrm{I} / \mathrm{R}+\text { Dex } 50 \\
\mu \mathrm{g} / \mathrm{kg})\end{array}$ & $\begin{array}{c}\text { Group } 4 \\
(\mathrm{n}=8) \\
(\mathrm{I} / \mathrm{R}+\mathrm{Dex} \\
100 \mu \mathrm{g} / \mathrm{kg})\end{array}$ & $\begin{array}{c}\text { Group 2R } \\
(\mathbf{n}=8) \\
(\mathbf{I} / \mathbf{R})\end{array}$ & $\begin{array}{c}\text { Group 3R (n } \\
=8) \\
(\mathrm{I} / \mathrm{R}+\text { Dex } 50 \\
\mu \mathrm{g} / \mathrm{kg})\end{array}$ & $\begin{array}{c}\text { Group 4R } \\
(\mathrm{n}=\mathbf{8}) \\
(\mathrm{I} / \mathrm{R}+\mathrm{Dex} \\
100 \mu \mathrm{g} / \mathrm{kg})\end{array}$ \\
\hline $\begin{array}{l}\text { Desquamation in } \\
\text { germinal cells }\end{array}$ & ND & +++ & ++ & ++ & + & + & + \\
\hline $\begin{array}{l}\text { Disorganisation } \\
\text { in germinal cells }\end{array}$ & ND & ++ & ++ & + & + & + & - \\
\hline $\begin{array}{l}\text { Degeneration in } \\
\text { germinal cells }\end{array}$ & ND & ++ & ++ & ++ & + & + & + \\
\hline $\begin{array}{l}\text { Haemorrhage } \\
\text { Interstitial }\end{array}$ & ND & ++ & ++ & ++ & + & + & + \\
\hline $\begin{array}{l}\text { oedema and } \\
\text { capillary } \\
\text { congestion }\end{array}$ & ND & ++ & ++ & ++ & + & + & - \\
\hline $\begin{array}{l}\text { Reduction in } \\
\text { germinal cell } \\
\text { counts }\end{array}$ & ND & +++ & +++ & ++ & + & + & + \\
\hline
\end{tabular}

ND: Not detected. 


\section{Discussion}

Testicular torsion is still an important factor in male infertility. Contributing factors, such as formation of free radicals and lipid peroxidation, are associated with testicular ischemia. As mentioned previously, ischemia occurring due to testicular torsion and reperfusion with detorsion of the twisted testicle can lead to various biochemical and morphological changes in the testicular tissue. Furthermore, post-ischemic reperfusion causes a further increase in the tissue damage and apoptosis ${ }^{13}$.

The general concept that testicular damage caused by a transient ischemia is associated with oxidative stress is supported by the rapid induction of lipid peroxidation and the accompany suppression of endogenous antioxidant activities such as SOD, catalase and glutathione peroxidase. On the other hand, the tissue injury induced by testicular T/D can be dramatically mitigated by pretreatment with exogenous antioxidants such as selenium ${ }^{14}$.

Although the exact mechanism of Dex in preventing I/R injury has not been elucidated, there are some opinions about this drug how exhibits its preventive properties for $I / R$ injury. Sympatholysis is one of Dex's properties as a result of its effect via presynaptic $\alpha$-adrenoceptors. By this effect, it is suggested that Dex reduces noradrenaline release that is induced by ischemia. The reduction of noradrenaline release in the circulation by Dex may prevent potential destructive effects caused by noradrenaline by means of preventing increased free oxygen radicals production $^{15}$. A further location of $\alpha_{-}$receptors are on blood vessels and vasoconstriction effect of Dex is due to the influence of $\alpha_{-}$agonists. Maier et al. ${ }^{16}$ suggested that Dex may improve perfusion of ischemic tissue by increasing vascular resistance to non-ischemic tissue "reverse steal effect," and hence decreases in blood flow may help to prevent the reperfusion injury caused by free radical formation and lipid peroxidation.

In the studies related to the anti-inflammatory effect of Dex in different tissues, Taniguchi et al. ${ }^{17}$ showed that Dex had an inhibitory effect on inflammatory response in lungs during endotoxemia in rats. Can et al. ${ }^{18}$ also reported the anti-inflammatory effect of Dex in spinal cord injury. In contrast, Nishina et al. ${ }^{19}$ declared that Dex had no influence on neutrophil functions in vitro.

The protective effect of Dex was examined in many different tissues with different doses in many experimental studies. A previous study showed that the administration of Dex after the $\mathrm{I} / \mathrm{R}$ period may produce no beneficial effect. However, when Dex was used preoperatively, it was proved to be more effective against I/R damage ${ }^{20}$. In our study, we have applied to the subjects of Dex i.p. 60 minutes before from the detorsion.
In an experimental study, Kocoglu et al. ${ }^{21}$ demonstrated that Dex can reduce the renal injury caused by I/R of the kidney and concluded that Dex may be useful in enhancing the tolerance of the kidney against ischemia. Similarly, Gu et al. ${ }^{22}$ showed that pre or posttreatment with Dex provided cytoprotection and improved tubular architecture and function after renal ischemia. However, Billings et $a l^{23}$ determined that the $\alpha_{-}$-adrenergic receptor agonists Dex and clonidine protect mice against radiocontrastinduced nephropathy by preserving outer medullary renal blood flow. In another study, Marangoni et al..$^{24}$ evaluated the effects of Dex on renal function and histology after acute hemorrhage in rats and concluded that Dex results in a beter renal function but higher tubular dilation scores after acute hemorrhage. Similarly, Villela et al. ${ }^{25}$ investigated the effects of Dex on the renal system and on vasopressin plasma levels in anesthetized dogs and found that low doses of Dex can protect kidneys during ischemia by inhibiting vasopressin secretion and leading to aqueous diuresis. Our results in the present study on testicular T/D-induced I/R injury are in accordance with the previous studies for the protective effects of Dex on renal tissue. However, Curtis et al. ${ }^{26}$ noted that ketamine plus $\mathrm{I} / \mathrm{R}$ injury was damaging to rat kidneys, according to histological changes, and Dex may not have completely protected the kidneys from these injuries.

Oxidative stress, resulting in an imbalance between the production of free oxygen radicals and antioxidant capacity, leads to damage of biological macromolecules and disruption of normal metabolism and physiology ${ }^{27}$. Reactive oxygen species (ROS) can attack the polyunsaturated fatty acid in the biological membranes and induce free radical chain reactions, leading to the enhancement of lipid peroxidation ${ }^{28}$. The methods used for the determination of oxidative stress are generally of board range. An often used and easily detectable parameter for the serum antioxidative and oxidant properties are the total antioxidant status (TAS) and total oxidant status (TOS) ${ }^{11,12}$. In our study, TAS, TOS and OSI parameters and histopathological changes were examined to evaluate the antioxidant capacity of increasing doses of Dex in a model of testicular torsion. Analyzing the antioxidant effects of increasing doses of Dex: In torsion and contrlateral testicles, Dex $100 \mu \mathrm{g} / \mathrm{kg}$ statistically significantly increases the tissue TAS and OSI when compared with Dex $50 \mu \mathrm{g} / \mathrm{kg}$ but has not been found significantly change on the tissue TOS. In the present study, we preferred to measure oxidants and antioxidant capacity simultaneously to evaluate oxidative stress more clearly and we measured oxidative stress with OSI which was detected using both oxidative and antioxidative parameters. We evaluated TAS which reflects the antioxidative status and TOS to investigate oxidative 
status using a more recently developed measurement methods by Erel $^{11,12}$.

In the testicular tissue, MTBS is used to assess histopathological damage. It is based on the evaluation of progressive degeneration of the germinal epithelium ${ }^{10,29}$. When the structure of the testis was histopathologically examined, it was observed that the histological appearance of testicular tissues of group 1 was normal. There were some histopathological changes such as degeneration, desquamation, disorganization in germinal cells, interstitial oedema and capillary congestion and hemorrhage in the ipsilateral and contralateral testis of rats in group 2. These histopathological changes were also present to a similar extent in ipsilateral and contralateral testis of rats from group 3,4. However, these histopathological changes were not significantly obvious in group 3,4. In the present study, in Johnsen's scoring system, statistically significant change has not been observed that despite application of the increasing treatment doses of Dex.

This study may support the other researches, which has been shown that ipsilateral testicular torsion causes a decrease not only in the ipsilateral torted but also in the contralateral nontorted testicular perfusion. Similar to Hanci et al. ${ }^{9}$ report, tissue TAS levels in administration of increasing treatment doses of Dex group were significantly higher than in groups $I / R$ and sham but no difference showed in histological level. The absence of antioxidant effect in the histopathological tissue can be explained by when significant increase of tissue OSI value considered with the absence of decreased tissue TOS value. We suggest that the effects of Dex might be seen as more long-term administration of i.v. infusions rather then i.p. may be useful in the histopathologic level.

This prospective experimental study has some pitfall. This study could not be supported by immunohistochemical and electron microscopic findings.

\section{Conclusion}

The antioxidant effects of dexmedetomidine on testicular ischemia-reperfusion injury in ipsilateral and contrlateral testis, but in the histopathological level, there was no difference statistically according to Johnsen's scoring system between groups at both sides.

\section{References}

1. Pentyala S, Lee J, Yalamanchili P, Vitkun S, Khan SA. Testicular torsion: a review. J Low Genit Tract Dis. 2001;5(1):38-47. PMID: 17043561 .
2. Williamson RC. The continuing conundrum of testicular torsion. $\mathrm{Br}$ J Surg. 1985;72:509-10. PMID: 4016528.

3. Akgur FM, Kilinc K, Aktug T. Reperfusion injury after detorsion of unilateral testicular torsion. Urol Res. 1993;21:395-9. PMID: 8171761.

4. Filho DW, Torres MA, Bordin ALB, Crezcynski-Pasa TB, Boveris A. Spermatic cord torsion, reactive oxygen and nitrogen species and ischemia-reperfusion injury. Mol Aspects Med. 2004;25(1-2):199 210. PMID: 15051328.

5. Cuzzocrea S, Riley DP, Caputi AP, Salvemini D. Antioxidant therapy: a new pharmacological approach in shock, inflammation, and ischemia/reperfusion injury. Pharmacol Rev. 2001;53(1):13559. PMID: 11171943.

6. Kanter M. Protective effects of melatonin on testicular torsion/ detorsion-induced ischemia-reperfusion injury in rats. Exp Mol Pathol. 2010;89(3):314-20. PMID: 20670623.

7. Mc Cutcheon CA, Orme RM, Scott DA, DavIes MJ, Mc Glade DP. A comparison of Dexmedetomidine versus conventional therapy for sedation and hemodynamic control during carotid endarterectomy performed under regional anesthesia. Anesth Analg. 2006;102:66875. PMID: 16492813.

8. Ramsay MA, Luterman DL. Dexmedetomidine as a total intravenous anesthetic agent. Anesthesiology. 2004;101:787-90. PMID: 15329604.

9. Hanci V, Erol B, Bektas S, Mungan G, Yurtlu S, Tokgoz H, Can M, Ozkocak Turan I. Effect of Dexmedetomidine on testicular torsion/detorsion damage in rats. Urol Int. 2010;84:105-11. PMID: 20173379.

10. Johnsen SG. Testicular biopsy score count-a method for registration of spermatogenesis in human testes: normal values and results of 335 hypogonadal males. Hormones. 1970;1:2-25. PMID: 5527187.

11. Erel O. A novel automated method to measure total antioxidant response against potent free radical reactions. Clin Biochem. 2004;37:112-9. PMID: 14725941.

12. Erel O. A new automated colorimetric method for measuring total oxidant status. Clin Biochem. 2005;38:1103-11. PMID: 16214125.

13. Ozbal S, Ergur BU, Erbil G, Tekmen I, Bagriyanik A, Cavdar Z. The Effects of $\alpha$-lipoic acid against testicular 1schemia-reperfusion injury in rats. Sci World J. 2012; 489248:1-8. PMID: 23193380.

14. Avlan D, Erdougan K, Cimen B, Dusmez AD, Cinel I, Aksoyek S. The protective effect of selenium on ipsilateral and contralateral testes in testicular reperfusion injury. Pediatr Surg Int. 2005;21:274-8. PMID: 15742187.

15. Hoffman WE, Kochs E, Werner C, Thomas C, Albrecht RF. Dexmedetomidine improves neurologic outcome from incomplete ischemia in the rat. Reversal by the alpha 2 -adrenergic antagonist atipamezole. Anesthesiology. 1991;75:328-32. PMID: 1677549.

16. Maier C, Steinberg GK, Sun GH, Zhi GT, Maze M. Neuroprotection by the alpha 2-adrenoreceptor agonist Dexmedetomidine in a focal model of cerebral ischemia. Anesthesiology. 1993;79(2):306-12. PMID: 8102042.

17. Taniguchi T, Kidani Y, Kanakura H, Takemoto Y, Yamamoto K. Effects of Dexmedetomidine on mortality rate and inflammatory responses to endotoxin-induced shock in rats. Crit Care Med. 2004;32:1322-6. PMID: 15187514.

18. Can M, Gul S, Bektas S, Hanci V, Acikgoz S. Effects of Dexmedetomidine or methylprednisolone on inflammatory responses in spinal cord injury. Acta Anaesthesiol Scand. 2009;53:1068-72. PMID: 19519725.

19. Nishina K, Akamatsu H, Mikawa K, Shiga M, Maekawa N, Obara $\mathrm{H}$, Niwa Y. The effects of clonidine and Dexmedetomidine on human neutrophil functions. Anesth Analg. 1999;88:452-8. PMID: 9972773. 
20. Zhang XY, Liu ZM, Wen SH, Li YS, Li Y, Yao X, Huang WQ, Liu KX. Dexmedetomidine administration before, but not after, ischemia attenuates intestinal injury induced by intestinal ischemiareperfusion in rats. Anesthesiology. 2012;116(5):1035-46. PMID: 22417965.

21. Kocoglu H, Ozturk H, Ozturk H, Yilmaz F, Gulcu N. Effect of Dexmedetomidine on ischemia-reperfusion injury in rat kidney: a histopathologic study. Ren Fail. 2009;31(1):70-4. PMID: 19142813.

22. Gu J, Sun P, Zhao H, Watts HR, Sanders RD, Terrando N, Xia P, Maze M, Ma D. Dexmedetomidine provides renoprotection against ischemia-reperfusion injury in mice. Crit Care. 2011;15(3):R153. PMID: 21702944.

23. Billings FT 4th, Chen SW, KIm M, Park SW, Song JH, Wang S, Herman J, D'Agati V, Lee HT. Alpha2-Adrenergic agonists protect against radiocontrast-induced nephropathy in mice. Am J Physiol Renal Physiol. 2008;295(3):F741-8. PMID: 18579700.

24. Marangoni MA, Hausch A, Vianna PT, Braz JR, Viero RM, Castiglia YM. Renal function and histology after acute hemorrhage in rats under Dexmedetomidine action. Acta Cir Bras. 2007;22(4):291-8. PMID: 17625668.

25. Villela NR, Do Nascimento JP, De Carvalho LR, Teixeira A. Effects of Dexmedetomidine on renal system and on vasopressin plasma levels. Experimental study in dogs. Rev Bras Anestesiol. 2005;55:429. PMID: 19468631.

26. Curtis FG, Vianna PT, Viero RM, Fiorio PM, Silva LM, Braz JR, Oliveira C, Castiglia YM. Dexmedetomidine and S(+) - ketamine in ischemia and reperfusion injury in the rat kidney. Acta Cir Bras. 2011;26(3):202-6. PMID: 21537522.

27. Trevisan M, Browne R, Ram M, Muti P, Freudenheim J, Carosella AM, Armstrong D. Correlates of markers of oxidative status in the general population. Am J Epidemiol. 2001;154(4):348-56. PMID: 11495858.

28. Zhu YJ, Zeng T, Zhu YB, Yu SF, Wang QS, Zhang LP, Guo X, Xie KQ. Effects of acrylamide on the nervous tissue antioxidant system and sciatic nerve electrophysiology in the rat. Neurochem Res. 2008;33(11):2310-7. PMID: 18470611.
29. Uguralp S, Bay KA, Mizrak B, Kaymaz F, Kiziltay A, Hasirci N. The effect of sustained and local administration of epidermal growth factor on improving bilateral testicular tissue after torsion. Urol Res. 2004;32:323-31. PMID: 15338084.

\section{Correspondence:}

Devrim Tuglu

Department of Urology, School of Medicine

Kirikkale University

71100 Kirikkale - Turkey

Phone: (0318)3335000-5439

Fax: (0318)2252819

devrimtuglu@gmail.com

Received: Feb 10, 2015

Review: Apr 11, 2015

Accepted: May 9, 2015

Conflict of interest: none

Financial source: none

${ }^{1}$ Research performed at Laboratory, Department of Urology, Faculty of Medicine, University of Kirikkale, Turkey. 